\title{
Music to my ears, but words to my eyes? Text, opera and their audiences
}

\author{
Lucile Desblache \\ Roehampton University
}

To Judi Palmer and Jonathan Burton, surtitlers at the Royal Opera House, Covent Garden

This paper discusses the translation of opera libretti throughout the history of the genre. Opera was born of a need to make words more prominent in vocal music and to express emotions through their musical setting. We shall first consider how attitudes to languages and to the audiences have impacted on different ways of providing translated versions of the operatic text through its relatively short history. Then, we shall focus on the most recent form of transfer available, on surtitling, show how it is governed by a desire for accessibility and is provided within the context of making classical music available to a wider and more diversified public.

\section{Introduction: words in opera}

From Confucius to Jaques Attali, thinkers through the ages have argued that music reflects the civilisation it belongs to but also expresses prophetic visions of society, anticipating historical and social developments to come through its own rules and styles. Although the power of music has always been notable in all human cultures, in the space of less than a century our ways of making, listening to and appreciating music have changed dramatically, essentially through the use of technology. This is particularly visible in compositions which combine words with music, as we now have the means to make the text as prominent or discreet as we wish, and it is the case in all vocal music genres, from pop to opera. I shall concentrate on the latter to show how the use of language and the transfer of languages in an artistic form which is often perceived as antiquated, pre-empted contemporary conceptions of the text in the past, and reflects the intricacies of our current polysystems.

In spite of a repertoire which mainly pre-dates the twentieth century and thrives on historical and mythological references, operas exemplify contemporary ways of conceiving, producing and perceiving text. Far from relating to the traditional notion of text as exclusively linked to verbal expression, words in opera are multimedial in that they are, both as signified and signifiers, part of several interdependent elements necessary to the meaning of the overall lyrical form. Paradoxically then, opera reveals non- 
binary cultural priorities which have very contemporary resonances: it is not about music or production or text competing for prominence in meaning as it used to be in the early history of opera, but about music and production and text (oral and written, particularly since the advent of surtitles) creating meaning interdependently. In addition, our current perceptions of libretti as intertextual, interlinguistic, transnational compositions fit our visions of text as various fragments which bounce off and back to the music in their quest for "difference and repetition", as the famous Deleuze title expresses (Deleuze 1968). Finally, attitudes to text in opera have changed very noticeably in the last two decades, reflecting a growing awareness of public demands as well as a need for political correctness. I would say that this drive towards accessibility, and particularly language accessibility, is diametrically opposed to the current trends in pop music. In rap for example, transparency of the words for a wide public is certainly not desirable, as slang aims at a particular target audience and a sociolect is created to express identity. Even in less rebellious vocal genres, the exotic or arcane qualities of lyrics are often part of the song appeal. Enya, currently one of the most successful female vocalist as regards commercial sales, includes in her album Amarantine (2005) a song in Japanese, as well as three in Loxian, a fictional language for which no translation is provided.

But I will stay with opera and before considering text and text transfer in its contemporary form, I will retrace attitudes towards the creation, translation and comprehension of libretti throughout Western history.

\section{Libretti in Western culture}

Although the history of song goes as far back as the first traces of human culture, the idea of systematically setting a non religious play to music, at least in the Western world, emerged at the Renaissance in Italy. Monteverdi's Orfeo, first performed in 1607 and considered nowadays as one of the first operas, was in fact entitled 'favola in musica' (fable in music). This reflects the fact that, as in all early lyrical works, a strong priority was given to the comprehension of the text. Vincenzo Galilei, father of the famous astronomer and opera pioneer, stated his intention to "imitar col canto chi parla" (imitate speech through singing) (Ghisi 1960: 1423). Marco da Gagliano, admirer of Peri and Monteverdi, also emphasised his desire to "scolpir le sillabe per bene imitare le parole" (sculpt syllables in order to truly imitate the words) (ibid.: 1438). In fact, as Susan McClary has pointed out, one of the reasons for the initial success of opera was the combined popularising of the music, through simpler, more touching melodies and use of texts based on Greek drama which appealed to the erudite nobility who sponsored the performances (McClary 1985: 154-155).

Librettists of these early compositions were called poets and libretti, poems until the eighteenth century. The word opera only appeared in 1659 when Robert Cambert and his librettist Pierre Perrin introduced it with 
the aim of suggesting a spectacle including dance, orchestral and vocal music, machineries and theatre. The term libretto emerged shortly after the birth of the opera, but it initially referred to a small booklet containing the words of a cantata, an oratorio, or any other vocal/lyrical piece, usually lavishly illustrated, available before performances. In fact, even though many librettists, such as Alessandro Striggio, were also musicians, "the music of early operas was rarely published, the libretto far more often" (Smith 1970: 11). This was not exclusively characteristic of Italian opera. Although Purcell was famous enough to be buried in Westminster Abbey, his name is often absent from programmes of the operas he composed, such as King Arthur, advertised as a "dramatick opera written by Mr Dryden". A few decades later, in 1759, Handel 'joined' Purcell in Westminster Abbey, but the fact that he was buried in the 'poets' corner' emphasises further the social prominence of poets over other creative artists of the time. In spite of a period of a few decades when machinery seems to have been the main source of entertainment, text grew in prominence as opera developed. The predominance of text and the power of librettists were to be felt throughout the second half of the eighteenth century. Lorenzo Da Ponte, following the death of the great Metastasio, was appointed as poet to the Imperial Theatres in Vienna in 1782. Mozart, also appointed as Imperial and Royal Court composer after the death of Gluck, had to suppress his distaste for rhyme in opera, bear with it, and compose. As for Da Ponte, he certainly expressed the idea of the text's prominence over the music with a confidence which seems out of place nowadays:

Mozart knew very well that without a good poem an entertainment cannot possess the merit of invention, design and a just proportion of the parts [...]. I think that poetry is the door to the music, which can be very handsome, and much admired for its exterior, but nobody can see its internal beauties if the door is ill-proportioned. (Holden 2006: 74)

Adapting and borrowing from other authors was common place for librettists until the nineteenth century. In particular, borrowing from a foreign text was an accepted practice. In poetry, textual variations on classical authors were sometimes even expected of poets, and this tradition persisted until the end of the nineteenth century. Let us mention for example Leconte de Lisle's Odes Anacréontiques and Etudes latines, set to music by several composers. Due to the influence of Lully, then Rameau, France's lyrical scene was relatively closed to foreign composers, which reflects what we might call today its protectionist policies. In England, the libretti of foreign operas tended to be adapted to English to suit both the music and the audience at the time. As Klaus Kaindl notes about eighteenth-century German opera (Kaindl 2004), these translation practices reflected society's attitudes towards the text. In Germany, where the ideas of the Aufklärung had established the sole importance of content and clarity in a text from the eight- 
eenth century, passages prioritising musical qualities in the texts such as arias and ensembles were sometimes not translated at all (ibid.: 46-47).

From the second half of the nineteenth century, attitudes changed visibly and the sensuality of the music increasingly took precedence over the words. In addition, composers truly took control of the text, sometimes, like Berlioz and Wagner, to write it themselves, sometimes, like Verdi, to insist on a full collaboration in the writing of the libretto. This tendency was visible in both comic opera and opera seria, and became strongly favoured by composers creating lyrical works based on the expression of a national culture, as we'll see below: Janáček, Tchaikovsky, Prokofiev, Britten... Moreover, until the mid-nineteenth century, successful librettists such as Felice Romani wrote a large number of works (around eighty libretti in the case of Romani who collaborated with Bellini and Donizetti). Yet the role of librettist was being challenged as, from that period onwards, composers wrote fewer operas. The trend, still visible today, towards a lesser number of new performances was initiated at the end of the nineteenth century. An astounding eight hundred new operas were performed at La Scala Milan between 1800 and 1900 (Livio 1985: 26). From the end of the nineteenth century, not only did composers take control of the text, but successful composers, rather than writing many works, composed a handful of operas intended to be performed in subsequent years. The case of Wagner who built a theatre in Bayreuth to host his compositions, performed there ever since, reflects this distinct change in attitudes.

Besides, the initial tradition of the same libretto, with perhaps some embellishments, used for several musical compositions, was entirely rejected. Twentieth-century composers often persuaded first-class writers to write libretti - Maeterlinck (Pelléas et Mélisande-Debussy), Colette (L'Enfant et les sortilèges-Ravel) Cendrars (La Création du monde-Milaud), Brecht (Die Dreigorschenoper and Mahagonny-Weill), W. H. Auden (Paul Bunyan-Britten), but being a librettist was not a full-time occupation any more. Many composers either worked very closely with a librettist or wrote their own libretti as Michael Tippett did for example.

Perhaps deterred by this rejection, but also following a trend of that time, Tippett went on to write the libretti of all his lyrical works himself. His contemporary Benjamin Britten never did but he insisted on a very close collaboration with his librettist:

One of the secrets of writing a good opera is the working together of poet and composer. [...T] he musician will have many ideas that may stimulate and influence the poet. Similarly when the libretto is written and the composer is working on the music, possible alterations may be suggested by the flow of the music and the libretto altered accordingly [...]. The composer and poet should at all stages be working in the closest contact. (Britten, interviewed by Newman 1947) 


\section{The language(s) of opera}

Born in Tuscany, the new genre of drama per musica naturally adopted Italian as its international language. Italian became the language of profane music; Latin remained the language of sacred music. After being established in Florence, Rome and Venice, Italian became strongest in Vienna at the end of the eighteenth century. In the seventeenth and eighteenth centuries, Italian opera, associated with aristocratic finesse while anticipating revolutionary concerns in its themes, competed with French opera sung in French, characterised by the strong presence of ballet and by simpler melodies which did not prioritise vocal virtuosity over the clarity of the words. French opera was essentially the product of Louis XIV's patronage and its orderliness, wary of Italian sensuality, reflected the oppressiveness of its ruler under the guise of French bon goût (McClary 1985: 155). When the king in later life shifted his interests towards more religious art forms, the genre went into decline until Gluck (and his librettist Calzabigi), keen to write simpler and briefer lyrical pieces than the elaborate Italian lyrical works in vogue at the time (operas could last up to six hours), rekindled some of the French principles. In doing so, he probably reassured an aristocracy concerned with visible signs of its loss of power. Italian remained the main operatic language until the nineteenth century but composers created operas in English, French and German from the seventeenth century, particularly in lighter lyrical pieces. In fact, it was all very puzzling: Lully, an Italian living in France, imposed French opera in French, Handel, a German living in England fought for the supremacy of Italian opera in Italian and throughout the eighteenth century, Vienna remained one of the strongholds of Italian opera. The latter became increasingly criticised for being "an exotic and irrational entertainment" (Johnson 1755) for the aristocracy, as Samuel Johnson noted in his dictionary, but it is only in the nineteenth century that national identities were fully visible in opera through the association of one country and one language.

Opera in translation was regularly performed in public theatres in England from the beginning of the eighteenth century, earlier in Germany where Italian opera was translated or adapted for small courts from the middle of the seventeenth century. The first Italian opera to be performed at Drury Lane in London in 1705, Thomas Clayton's Arsinoe with an original libretto of T. Stanzani, was sung in an English translation by English singers. Handel invested a great deal of artistic and financial energy to promote opera in Italian, but in England, vocal and lyrical pieces in English were mostly favoured by the public. Interestingly, Handel's operas are still at their most popular in translation in England. It was not unusual for operas to be offered half in Italian, half in the language of the country in which they were performed. Often, the arias were sung in Italian while recitatives were sung or spoken in another language. Different roles were sometimes even sung in different languages. This remained relatively common until 
the mid-twentieth century, as singers often imposed the language in which they sang. Peter Newmark, an opera enthusiast, told me for instance of a performance of the Marriage of Figaro attended in Brno in 1938, when Susanna sang in Italian whilst the rest of the cast sang in Czech. Although lighter opera and singspiel were generally composed in a range of vernacular languages, opera seria was associated with Italian and French until the end of the eighteenth century. For example, Catherine the Great of Russia, a passionate opera supporter, wrote no fewer than nine opera libretti in French or Italian and commissioned established Russian composers to write music for her. The quasi exclusive use of French and Italian was abandoned from the beginning of the nineteenth century for two main reasons: the first was the emergence of strong national identities in Europe expressed in all artistic forms, including music; the second was the trend towards more realistic operas, less mythological texts, initially driven by the encyclopaedists, particularly Diderot, who favoured lyrical works inspired by aspects of new bourgeois ideals. Increasingly, from the nineteenth century onwards, libretti were written in prose or in mixed prose and verse rather than exclusively in verse, and were based on social and contemporary themes. Alfred Bruneau, a famous composer in his day and an influential music critic, for example, wrote several operas on libretti by Emile Zola.

Soon, the lyrical repertoire expanded into a wide range of European languages, this expansion prophesying perhaps, as Attali would argue, a "recreation of difference" (Attali 1985: 145) and anticipating some of the political and social European developments to come. Italian librettists and composers had a very strong operatic tradition to follow. Yet, Italy, France, and perhaps German-speaking countries apart, this was not the case in the rest of Europe where composers could not base their lyrical works on an established practice and where audiences needed to be introduced to local versions of the genre in fresh and appealing ways.

The cultural expression of new nationalisms was visible in all artistic forms but gave a new breath of life to opera. Composers tended to be inspired by their literary compatriots rather than turn to the conventions of mythological or classical themes. This meant greater variety in topics through a wide range of works expressing burgeoning national identities: Mussorgsky, Rimsky Korsakov and Tchaikovsky adapted Pushkin, Prokofiev Brussov, Janáček Preissova, all significant literary compatriots who contributed to establishing a national culture liberated from French, Italian, or German influence. Since opera was (and still is) a very expensive form of cultural production, emancipation from the dominant cultures wasn't always straightforward. In those heydays of nationalism, the choice of a language could be a sensitive political issue. Jenůfa, Janáček's lyrical masterpiece for example, although premiered in Brno in Czech in 1904, was performed in German for the Viennese Court Theatre with the composer's consent. He was heavily criticised both by Czech compatriots who felt that "in allowing his opera to be played in a German theatre, Janáček did not preserve his national honour" and by some Germans who claimed that "at a 
time when the Czech soldiers betrayed the Empire by going over to the enemy, it would be improper to perform a Czech nationalist opera on the official stage in the capital...." (Krejči 1985: 11). This German version, by Max Brod, a well-known German Jewish literary figure of the time, was instrumental in etablishing Jenufa on the international scene. Yet an opera in a certain language was becoming a statement of identity, and complying with dominant languages often implied betrayal. A trend towards performances of operas in translation into the language of the country where they were performed was established in the nineteenth century. As opera houses such as The Metropolitan Opera, Covent Garden, La Scala, became established and devoted themselves exclusively to the operatic repertoire, they opted on the whole for the original language while provincial opera houses offered works in translation. Nowadays, it is interesting to note that although contemporary opera, albeit a rarefied genre, is far from being extinct, works that have a large impact on the public are generally set on libretti in English. The composer Gian-Carlo Menotti, although resident in the US for most of his adult life, retained his Italian nationality throughout his life and set up an international opera festival in Spoleto and various other ventures to ascertain his Italian identity. Nevertheless, he wrote all the libretti of his operas, some of which had considerable success, in English. In this respect, the dissemination of opera today is not different from that of media and literature. It functions in a global setting where English dominates. Yet, and paradoxically for a genre steeped in tradition and often criticised for its highbrow focus, opera is the only artistic form which carries its repertoire in Italian, French, German, Russian and a few other languages, making multilingualism today more visible than in any other creative strand.

\section{Audiences and opera}

This diversification of languages away from Italian and French which were tongues expressing the questionable universality of the powerful, certainly revealed cracks in the polish which "legitimat[es] social differences" and asserts "the superiority of those who can be satisfied with [the sacred sphere of culture, that is] the sublimated, refined, disinterested, gratuitous, distinguished pleasures forever closed to the profane" (Bourdieu 1986: 7). From the end of the nineteenth century onwards - some would say earlier, as the 1809 Covent Garden riots in protest of price increase testify, opera, as a prime manifestation of this cultural sphere of exclusion for social and financial reasons, was being challenged in a society which did not openly want to admit policies of exclusion any longer. This was not entirely the case in Italy, where the lyrical tradition had also to a large degree been aimed at local people and been composed for them. As opera reached beyond the spheres of private performances for the aristocracy to be available in public theatres (initially in Venice from 1637), the social and popular 
aspects of operatic performances became increasingly significant. A tradition of very noisy shows was established in theatres and opera houses in the seventeenth century. Audiences were moving and speaking as they pleased during the performance, in an auditorium which was fully lit. Even in France and in England, where the public was supposed to be more restrained than in Italy, spectators could walk on the stage at any time until the second half of the eighteen century:

In operatic productions of the early eighteenth century it was the prima donna's mother, maidservant and admirers who crowded the stage, armed with mirrors, combs and smelling salts to restore her between arias. [...S]eats on the stage were abolished at the Comédie Française in 1759 and at the Drury Lane Theatre in 1762. (Howard 1981:15)

The confusion that ensued, to the despair of composers and librettists, probably influenced the expansion of visual elements in opera. Indeed the weight of the chief machine engineer regarding decisions in opera productions in the first half of the eighteenth century was as important as those of the librettist and composer. Yet most European opera houses hosted shows attended by the middle and upper classes who wanted to be seen and accepted into an exclusive social circle. The large majority of the audience only went to the opera for a fraction of the performance, and a theatre black-out only became common in the later part of the nineteenth century. The audience certainly did not give priority to the continuity of the operatic plot, which may explain why the same repertoire was offered, as the account below, written at the end of the nineteenth century suggests:

L'opéra compte un grand nombre d'abonnés, mais qui sont ces abonnés? Des gens riches. [...] Que viennent-ils faire? Voir, se faire voir, écouter un acte, causer dans les entractes, applaudir un air, acclamer un pas de danse; mais combien y en a-t-il parmi eux qui entendent la première mesure d'un opéra et ne partent qu'après la dernière? (Menger 1985: 55)

[The opera house has a great number of regular subscribers, but who are these subscribers? Rich people. [...] Why do they come? To see, to be seen, to listen to an act, to chat during the intervals, to applaud an aria, to acclaim a few steps; but how many among them do listen to the opera from the first bar and only leave after the last?] (translation LD).

In contrast to this elite audience, a new public of opera connoisseurs and music lovers grew in the course of the nineteenth century. They watched operas often sung in translation in theatres offering more affordable tickets. A rift between prestigious houses offering performances in the original language and more modest institutions producing translated versions appeared. 
As the standard repertoire dwindled to a few dozen operas, the public generally went to see and hear pieces which they knew or which they had heard of. A black-out in the auditorium throughout the performance, instituted from the mid-nineteenth century onwards, prevented opera goers from reading libretti during the performance. Most operas were performed in translation. In spite of this, many opera goers came armed with opera glasses, a torch and either a libretto (which they could purchase in the theatre) or a small vocal score where they could read the singers' melody and text, generally in translation. In France, a collection entitled "L'Opéra populaire" offering the operas in vogue testifies that operas were mostly performed in translation when not originally written in French and that a large proportion of the public was keen to follow the music and able to read it. However out of the forty-five titles available in that collection at the beginning of the twentieth century, only five were by composers who did not use an original libretto in French (Mozart, Mascagni and Verdi were the composers).

During the first half of the twentieth century, opera in the language of the country where it was performed was the norm, certainly in provincial European houses. Two world wars also had an impact, strengthening national language use. In Great Britain for example, throughout the Second World War, during which international theatre was suspended, an interest in opera in English was rekindled, though this was largely because of a new repertoire composed for the English language and because orchestras tended to be reduced to chamber size, rendering the comprehension of the singers easier. The general attitude of the post Second World War public towards prestigious opera houses offering performances in original languages was threefold: those not interested or marginally interested in opera resented the large subsidies granted to a far too exclusive form of entertainment; the connoisseurs preferred to attend performances in the original language, but could not always afford them; those curious about opera, living outside capital cities, or those who could not afford international houses' prices would fall back on the less costly adaptations available. If translators through history have often been the poor relatives of writers, opera in translation generally was the lesser cousin of original versions, produced within a more modest budget at all levels. The expanding number of pieces added to the operatic repertoire from the second half of the twentieth century and the demands made by both the public and subsidising organisations for more accessibility to the genre gave increasing priority to the comprehension of the text.

In the social climate of the nineteen eighties, as public funds became available not only to traditional artistic ventures but to less conventional ones, subsidising opera, still seen as a form of entertainment for the privileged few, was increasingly criticised. The tumultuous history of the Royal Opera House at the end of the twentieth century bears witness to this and is a good example of how perceptions and expectations changed throughout Europe. The Royal Opera House came very close to closing down, as did several other European opera houses at the time, and the Arts 
Council, which had originally funded the institution and supported it since 1946, only granted it its backing on condition that services to the public would be drastically improved. This included providing education and outreach programmes, some free events, improving the accessibility of opera and in particular the comprehension of the language. This is the context in which surtitles were adopted in European opera houses, altering dramatically the perception and reception of operatic text.

\section{Visible surtitles and invisible surtitlers}

Much has been written about opera houses' need to coax their public and their providers of funding through a more open policy (Storey 2003; Ranan 2003; Kolb 2000), visible in the implementation of surtitles. Once instated, they provoked an enormous amount of resistance, essentially from conductors and producers who feared that an unavoidably visible text would divert most of the public's attention to the script). A number of music critics joined this chorus of dissent, implying that opera companies were hypocritical in providing this visible accessibility gadget while remaining as exclusive as ever, as Andrew Clements, music critic for The Guardian stated:

[...W]hatever Hall may say about ridding the Royal Opera House of its aura of inaccessibility, it is hard to perceive any change in the atmosphere when one goes there. The place receives almost $£ 20 \mathrm{~m}$ in public subsidies for its ballet and opera companies combined, yet as Gerald Kaufmann observed to the House of Commons culture committee earlier this week, it still conveys the image of being an exclusive club - far more so, to my eyes and ears, than Glyndebourne, which receives no government grant. Chauffeur-driven limos still queue outside the theatre during intervals, just in case their owners find one act of an opera more than enough; a round of sandwiches in the upstairs cafeteria still costs more than $£ 8$; tickets to see an ageing tenor in a 40-year-old production still range up to $£ 175$. And allowing Björk to give one concert in the building will hardly bring a new audience flocking into the theatre for opera and ballet. (Clements 2002)

Producers and conductors were, and mostly still are unequivocally irate:

"Surtitles are," said David Pountney, [...] "a celluloid condom inserted between the audience and the immediate gratification of understanding."

Sir Peter Jonas, now head of the Bavarian State Opera, said: "If ENO are doing what the audience wants, they should have public executions on the stage of the Coliseum. After all, the public wants capital punishment.” (Higgins 2005) 
Such attitudes certainly do not promote the visibility of the translator sought after by so many scholars and practitioners. First of all, because the translator is at the centre of a controversy which denigrates translation work and the importance of translation; second, because s/he is perceived more than ever as anonymous. It would seem that although translation is definitely becoming more visible in the world of opera, the translator is remaining as invisible as ever. Operatic adaptations sung in a foreign language have a certain status and their creators may acquire a certain visibility, such as Richard Stokes or Amanda Holden, but surtitlers tend to remain unseen.

Surtitlers are keen to render the text comprehensible for the audience, but also, to be in harmony with the production (and if possible with the producer). Jonathan Burton, surtitler at the Royal House, recommends avoiding information overload at all cost: "[A]lways aim to be brief and simple" and be aware that "members of the audience have come to hear the singers, not to read your text" (Burton 2001). This humble approach implies not only attaining "unobtrusiveness of style - an easily digestible neutrality" (Low 2002: 106) which may be desirable if the libretto is of poor quality and shows its age considerably, but which may also be frustrating for the surtitler, as it would be to any translator, it also means matching decisions made by producers which are sometimes contradictory to the original text. This is often the case when scenes are set in a different period from the original. Peter Low comments on his translation of Les Pêcheurs de perles, which had to be adapted during rehearsals when he "discovered that there would be no tents on stage, no stand, no canoe, and no incense - despite their unambiguous presence in the ST" (ibid.: 107). Indeed, he notes that on this occasion, the "director rejoiced that his audience's general inability to follow the French gave him more freedom to ignore certain words being sung" (ibid.). As Riitta Virkkunen reminds us, "opera is multisemiotic and multimodal in nature" (Virkkunen 2004: 91) and regardless of demands made by producers, directors or conductors, the interpretation of operatic text is not exclusively bound to text but also largely depends on visual, musical and emotional elements present throughout each performance. Opera and theatre surtitles require flexibility of timing as they are issued for each performance and also, to some degree, of meaning, as each production and at some level, each performance gives a new meaning to the work interpreted.

Is libretto, the dramatic text, really the source text of surtitles, as the articles cited above suggest? Or should we consider the stage interpretation to be the source text, which means that we acknowledge the entity of an opera performance instead of dividing the operatic whole into text (libretto) and context (other semiotic modes)? In my opinion, I think we should (ibid.: 95). 
This justifies to some extent the need for neutrality in a translation which has to be flexible enough to encompass changes as inevitable as they are desirable. This neutrality may also be used as a discreet way of remaining objective with regard to the particular production presented, of proposing a text which like the music, remains much more permanently part of the work of art. Like interpreters, surtitlers aim for an invisibility which enhances the comprehension of the text without taking precedence over other operatic components.

Self-effacement of the text need not lead to self-effacement of the translator. Yet, in a cost-cutting exercise, surtitlers in opera houses are often full-time members of staff, such as librarians or stage managers, who are given surtitling as part of 'new post responsibilities', often without a great deal of training. If mentioned at all, they tend to be listed at the back of the programme with the directory of permanent members of staff. Translation for surtitling purposes usually takes place in two stages. The libretto is translated by a translator, or an existing translation is suggested in the first instance and the translation is then adapted to the requirements of surtitling to be delivered live for each performance. In some cases, the two roles are filled by the same person. However, at best, the member of the public who really looks for the small print will see a notification, often not acknowledging translators by name. In the case of the English National Opera where all performances are in English, the translator is usually given recognition, even though the surtitler's credits are relegated to the "ENO Board and staff page" where, those who have very good eye sight, we can find the name of a "Music Librarian and surtitles operator" (King Arthur 2006). Even in the few opera houses in the world where dedicated members of staff are employed, such as the Royal Opera House in London, the visibility of the translator is far from obvious. In July 2006, the Bolshoi Opera gave some performances at the Royal Opera House. Even though the interpreters used during that period to establish smooth communication between the British and the Russians are clearly listed in the programme, no mention is made either of the libretti translators of the two Russian operas produced (Prokofiev's Fiery Angel and Mussorgsky's Boris Godunov) or of the Royal Opera House surtitler who adapted these translations and made them appear on stage. In home productions, the surtitler has recently been mentioned in the small insert that accompanies the programme.

\section{Opera audiences and surtitling}

In spite of the spectacular rage expressed by a number of leading professionals in opera, the public is very nearly unanimously hungry for surtitles. A few opera connoisseurs lament the fact that "with surtitles, the audience has no choice [and that] while this may be helpful in some areas of the repertoire, in the field of vernacular comedy it is death. The vital contact between performer and audience is broken" (Shore 2006: 1424) ${ }^{2}$. However, 
"they are here to stay" (Bredin 2005), as surtitles are overwhelmingly requested by the public. All surveys show their popularity. They are popular even when there is no language transfer issue, i.e. when the text is sung in the native tongue of the country. The English National Opera, before deciding to opt for a surtitling policy in spite of the fact that their repertoire is entirely in English, undertook a survey and found that " $61 \%$ of its audience was more likely to return to the Coliseum if surtitles were used" (BBC 2005).

These statistics are interesting if we compare them with the recent rise in opera attendance in the Western world. The U.S. opera audience grew by 35\% between 1982 and 1992 for example, and this trend continued through 2002, when the opera audience grew by an additional 8.2\% (Opera America website). Although more stable in Britain, figures also show an increase in the rest of Europe.

In this light, my colleague Jacqueline Page and I undertook a small survey, essentially among music students and colleagues whom we knew attended opera performances. We also distributed questionnaires at an amateur operatic performance. Altogether we gathered forty five sets of answers. The table below will give some indication of the participants who took part in the survey in the summer and autumn 2006:

Table 1: Survey on surtitling

\begin{tabular}{|l|l|l|l|}
\hline \multicolumn{1}{|c|}{ Age group } & $\begin{array}{c}\text { Native } \\
\text { speaker of } \\
\text { English }\end{array}$ & \multicolumn{1}{|c|}{ Goes to the opera } & \multicolumn{1}{c|}{$\begin{array}{c}\text { Are you a } \\
\text { professional } \\
\text { musician/singer? }\end{array}$} \\
\hline $\begin{array}{l}\text { Under } 25: 11 \\
\text { 25-35: } 3\end{array}$ & Yes: 32 & Very rarely: 18 & Yes: 4 \\
35-45: 6 & & Once a year: 6 & No: 38 \\
$45-60: 16$ & & 2-6 times a year: 17 & Training to be: 3 \\
$60+: 9$ & Once a month or more: 4 & \\
\hline
\end{tabular}

Participants were overwhelmingly positive about surtitling. Only three participants answered that they were not in favour of it. Two out of these three did not answer the question asking to rate whether they preferred opera in translation in the original language without surtitles, in translation without surtitles, in translation with surtitles and translated with surtitles. The third participant was inconsistent in his/her opinion as s/he wrote that all performances should be surtitled later on in the survey.

Out of the ten participants who were not against surtitling but who answered that surtitling was disturbing during the performance, eight nevertheless thought that some if not all performances should be surtitled, one wrote that it depended on the surtitles and one (a professional singer) was of the opinion that all performances should be surtitled. Sadly, only one 
participant (a retired musician) suggested that the obtrusiveness of surtitles was directly dependent on the quality of the surtitles.

This small-scale survey not only confirms statistics given by larger organisations, but its figures show even more support for surtitles. This enthusiasm also reveals different expectations of the text. Whilst for most nineteenth-century audiences the translated text was meant to be sung and heard, nowadays, it is intended to be read, and visibly integrated on stage, emphasising the multimedial and multimodal essence of opera in contemporary societies which undoubtedly prioritise the visual.

\section{Conclusion}

A few decades ago, the future of opera seemed uncertain. Prestigious opera houses survived, but many smaller institutions, such as the Opéra-Comique in Paris closed or were used for different purposes in the seventies and eighties. The rekindled interest in opera, noticeable at the turn of the last century, may be reflecting European nostalgia for visions of a culture that has gone by. But it also mirrors other priorities firmly linked to our present and happens in response to successful efforts made by opera houses and festivals to be culturally and financially more accessible to a wider public. The growth in opera attendance visible in the last two decades and the desire of the public to see a variety of works rather than standard nineteenthcentury repertoire are the results of a range of undertakings from educational projects to touring ventures. Yet, the most significant of these is in my view the widespread availability of the libretto (or part of it) in one's native language, which allows comprehension of the narrative whilst not interfering with other essential elements of the creative performance

This is not just important as regards the comfort of the audience and ticket sales. It also has major implications concerning languages in general. At a time when English has become the lingua franca, most people are exposed to two languages at most. Opera is not only multimedial, it is also mutilingual. Most anglophone speakers evolve in a monolingual social and cultural environment. Opera is one of the few genres which can break this barrier. In addition, the fact that the plot can be understood has an impact on the output of operatic works. Composers know that the text of their librettist will be understood by the audience. Opera directors know that the narrative will be followed. The perpetuation of an operatic repertoire which did not renew itself was partially due to the difficulty of grasping the text, either because the sung translation was only partially understandable, or because it was not provided in performance. At the beginning of the seventeenth century, Italian musicians invented opera primarily because they felt that the intricacies of the polyphonic system dominating music at the time did not allow the audience to understand words in combination with music. Today in opera performances, not only is the text available to us, but it is available simultaneously in a wide range of forms: in translation, as a sum- 
mary of the libretto and in the form in which it was intended to be performed and sung on stage, live. If Jacques Attali (2006) is right in his argument that musical forms preempt social events, then perhaps the fact that we are providing a cultural genre which combines different and simultaneous types of texts may anticipate not only complex communication issues but our capacity to read our world multimodally. Opera translators and surtitlers are making another layer of understanding and enjoyment available to us. To do so, they need not only a wide range of linguistic and musical skills but also in depth knowledge of operatic cultural background and an artistic sensitivity. They aim for their output to be if not invisible at least sufficiently unobtrusive, that we may understand but only focus fleetingly on their words. The sad part of the story is that the more successful they are at providing a relevant but discreet text, the more likely we are to take them and their talent for granted. For this reason, this paper is dedicated to the surtitlers of Royal Opera House, with thanks, because of what they do, in the hope that it will contribute to their visibility.

\section{Bibliography}

Attali, Jacques (2006). Noise, The Political Economy of Music. (trad. Brian Massumi). Theory and History of Literature vol. 16. Minneapolis/London: University of Minnesota Press, originally published in French as (1977) Bruits: essai sur l'économie politique de la musique. Paris: Presses Universitaires de France.

Bourdieu, Pierre (1986). Distinction, A Social Critique of the Judgement of Taste. London: Routledge, translated by Richard Nice, originally published in French as (1979) La Distinction, Critique sociale du jugement. Paris: Les Editions de Minuit.

Burton, Jonathan (2001). "Writing surtitles". Paper presented at the Royal Opera House, London

Bredin, Henrietta (2005). "Lost in Translation". The Spectator, 4 June.

Clements, Andrew (2002). "Cashing in at Covent Garden”. The Guardian, 12 January.

Deleuze, Gilles, (1968). Différence et répétition. Paris: Presses Universitaires de France.

"English operas to get surtitles". BBC News (2005). 7 June. http://news.bbc.co.uk/go/pr/fr//1/hi/entertainment/arts/4070856.stm. (last visited on 10 December 2007).

Ghisi, Federico (1960). "La réforme dramatique". Roland Manuel (ed.) (1960). Histoire de la musique vol. 1. Encyclopédie de La Pléiade. Paris: nrf, 1420-1441.

Higgins, Charlotte (2005). "Can you hear me? ENO war of words". The Guardian, 8 June.

Holden, Anthony (2006). The Man Who Wrote Mozart. The Extraordinary Life of Lorenzo Da Ponte. London: Weidenfeld and Nicolson.

Howard, Patricia (1981). C.W. von Gluck. Orfeo. Cambridge: Cambridge University Press.

Johnson, Samuel (1755). 'Opera' entry in Dictionary of the English Language. Printed by W. Strahan, for J. and P. Knapton et al. Vol.2. London. No page number.

Kaindl, Klaus (2004). "Normes et conventions dans la traduction des livrets d'opéras". Gottfried R. Marschall (ed.) (2004). La Traduction des livrets. Aspects théoriques, historiques et pragmatiques. Paris : Presses de l'Université Paris-Sorbonne, 43-54.

Kolb, Bonita, M. (2000). Marketing Cultural Organisations. New Strategies for Attracting Audiences to Classical Music, Dance, Museums, Theatre and Opera. Dublin: Oak Tree Press.

Krejči, Jaroslav (1985). “A National Composer”. Janáček, Jenůfa, Katya Kabanova. Opera Guide 33. London: John Calder, 7-12.

Livio, Antoine (1985). "Du côté des metteurs en scène". in Philippe Olivier (ed.). Autrement $n^{\circ} 71$ Opéra, Juin, 26-30.

Low, Peter (2002). "Surtitles for Opera: A Specialised translating Task". Babel 48 (2), 97-110.

McClary (1985). "Afterword” in Jacques Attali Noise: The Political Economy of Music (translated by Brian Massumi) Minneapolis/London: University of Minnesota Press . 
Menger, Pierre-Michel (1985) in Philippe Olivier (ed) (1985) "Voir ou être vu?". Autrement $n^{\circ} 71$ Opéra, Juin, 53-57.

Newman, Ernest (1947). "Albert Herring", The Sunday Times, 6 July.

Opera America http://www.operaamerica.org/pressroom/quickfacts2006.html. (last visited on 20 November 2007).

Programme for the Bolshoi Opera on tour, The Fiery Angel/ Boris Godunov (2006). Royal Opera House London.

Programme for King Arthur (2006). English National Opera. London.

Ranan, David (2003). In Search of a Magic Flute. The public funding of opera-Dilemmas and decision making. Oxford/Vienna: Peter Lang.

Shore, Andrew (2006). "Readers' letters". Opera. December 2006, 1423-1424.

Smith, Patrick (1970). The Tenth Muse, A Historical Study of the Opera Libretto. New York: Alfred A. Knopf.

Storey, John (2003). Inventing Popular Culture. From folklore to globalization. Oxford: Blackwell Publishing, 74-77.

Virkkunen, Riitta (2004). "The source text of opera surtitles". Méta 49(1), 89-97.

\footnotetext{
${ }^{1}$ The first page of King Arthur, published in London in 1694, is reproduced in the English National Opera programme issued for King Arthur in 2006. No mention of Purcell is made. First performance of the opera took place in 1691.

${ }^{2}$ This is an interesting remark if we consider that the operas which have been most consistently performed in translation throughout the second half of the century and up to now tend to be lighter operas. The Bartered Bride, Orpheus in the Underworld, The Merry Widow and other comic opera classics are still often performed in translation where more serious opera rarely is nowadays. This is not only the case in the UK, but also in the rest of Europe. The argument is on the contrary that this "contact between performer and audience" is enhanced by the translation. Fair to say, surtitles do insert an extra layer of communication which is not conducive to
} spontaneity, particularly in very fast and witty exchanges. 